\title{
Peeling Indicator
}

National Cancer Institute

\section{Source}

National Cancer Institute. Peeling Indicator. NCI Thesaurus. Code C154883.

An indication as to whether there is the presence of peeling. 